\title{
CONSERVATION AGRICULTURE: A “GREENER” SOLUTION FOR IMPROVING AGRARIAN DISTRESS IN INDIA
}

\author{
Uday Das \\ Research Scholar (UGC Junior Research Fellow) \\ Department of Lifelong Learning \& Extension, Rural Extension Center \\ Visva-Bharati, Shanti Niketan, India \\ Email: Udaydas948@gmail.com
}

\begin{abstract}
Gradual degradation of agricultural production and dilapidation of soil fertility is a serious disquiet for sustainable agriculture. International research and development organization developed a conservation agriculture approach to achieve a sustainable path for agriculture. Indian agriculture sector becomes a less profitable, thankless, and back-breaking profession. Gradual land degradation, falling soil fertility and crop failure have reduced agriculture production. To keep continuous production, conservation agriculture is an alternative sustainable method to overcome the situational constraints in any type of land and environmental situation. This study tries to identify major agrarian distress in India by using CSO, NCRB and annual agriculture report data. The study also reviewed numerous articles, journals and research paper to analyse potential CA system paradigm as a greener solution to check gradual land degradation, reduced greenhouse gas emissions and improve soil health for sustainable agriculture production in India.
\end{abstract}

Key words: Conservation Agriculture, Land Degradation, Soil Health, Agrarian Distress

\section{Introduction}

Volatility in growth rates and regional or spatial disparities in agricultural performance is a serious puzzle in India. From few decades' agriculture percentage share of GDP and the ratio of the rural net domestic product has declined (Gulati et al., 2012). It is high time has to think agriculture as an agribusiness rather than subsistence agriculture (M S Swaminathan). More than 50 per cent workforce still directly engaged in agriculture. Rural population and their livelihood, directly and indirectly, dependent on agriculture. Indian agriculture is conventional, subsistence, traditional, and rainfed in nature, which is dying as a pleasant profession. Conventional agriculture practices are labour, Water, and energy-intensive and it becomes less profitable (Chauhan et al., 2012). Subsistence farming is a thankless, risky and backbreaking profession (R. Tongia 2019). Over two-thirds (nearly 60 per cent) of Agri-land of India is rainfed and suffered by droughts, flood and climate change, that reduced agriculture production (Neate 2013). Subsistence agriculture denotes poor economic development and low productivity (Heidhues \& Bruntrup 2003). Many researchers have been described, Indian agriculture (rainfed, traditional, conventional, and subsistence) system is a gamble of monsoon and climate because farmers face many climatic uncertainties (Sharma \& Soni 2006; Dwivedy 2011; \& Neate P. J. 2013). Climate change reduces crop production, which promotes poverty and food insecurity. India needs to implement sustainable agriculture technique.

During the period of the green revolution (the early 1970s) wheat and rice performed an important role in food security. Extensive cultivation of wheat and rice in a system mode for the last few decades, creating some threats towards the sustainability of the rice-wheat system 
(Chauhan et al., 2012). Conventional systems are widely practised in India, that's characterized as intensive tillage, which is a prominent factor for the continuous decline in soil organic matter. moreover, Irreversible degradation of groundwater level, deterioration of soil, falling soil fertility, input cost increasing and profit decreasing is current serious problems in the Indian agriculture sector. In this context, Indian farmers need farm innovations that will help them to enhance production to support their livelihood with agricultural sustainability. Further Indian agriculture sector needs "evergreen revolution" (the term coined by M S Swaminathan) for the enhancement of agriculture productivity. Conservation farming is an excellent method for sustainable management of soil and water, and more effective to enhance the soil health (M S Swaminathan). Water erosion, acidification, flooding, wind erosion and salinity are major factors for soil degradation in India, conservation agriculture approaches are potential solutions to check gradual degradation of soil and effective measures to improve soil health (Bhattacharyya et al., 2015). Conservation agriculture has risen as a green paradigm to achieve sustainable agriculture production (Abrol \& Sangar 2006). This paper aims to explain and identify the potential of conservation agriculture as a sustainable and "greener" farming practice in the context of Indian agrarian distress.

\section{Conservation Agriculture}

Conservation agriculture implies three interlinked principles, direct seeding without soil disturbing and manage crop residues and applies crop rotations for improving soil fertility (FAO). Over one-third soils of the planets are degraded; conservation agriculture is an alternative to regenerating degraded land and preventive measures for losses of arable land (FAO). Direct seeding reduces farming cost and greenhouse gas emission (Hobbs et al., 2008). Tillage takes more time for planting of crops but zero tillage minimizes time for establishing a crop (Hobbs et al., 2008). The conservation agriculture introduced farming crops without tilling the soil (no-tillage), which contain minimum soil disturbance and management of soil organic matter. Highly mechanized traditional agriculture is consuming more groundwater and responsible for soil erosion. Hence conservation agriculture method offers a permanent soil cover and effective for improving soil organic matter in surface horizons (Bhan \& Behera 2014). Mono-cropping under conventional agriculture system will not adequate to achieve production goal and ensure food security for the future. To keep continuous production, conservation agriculture is an alternative sustainable method to overcome the situational constraints in any type of land and environmental situation (Ghosh et al., 2010). Conservation agriculture considered as a climate regulator, which is sound to regulate greenhouse gases and serve as a global warming remission strategy (Almaraz et al., 2009). Conservation agriculture system has been introduced successfully in the rice-wheat region of South Asia and that reduced erosion and runoff and improved underground water quality compared to conventional agriculture practices (Dendooven et al., 2012; Palm et al., 2014). Traditional monoculture has responsible for soil degradation with low nutrient content and soil organic matter. Conservation farming is a sustainable alternative for maintaining physical, chemical and biological qualities of soil (Govaerts et al., 2007; Kassm et al., 2009) and also maximize ecosystem service functions and biodiversity (Sanderson et al., 2013; Palm et al., 2014). Conservation agriculture is a "greener" solution to reduce accelerating soil degradation, threats of climate change and CA also helpful to improve the soil fertility, and highly beneficial to reducing soil erosion and generally increase infiltration (Thierfelder et al., 2013; Giller et al., 2009). Conservation agriculture is a resource-saving agriculture practice, which is effective for enhancing the natural biological processes above and below the ground (Kassam et al., 2009).

\section{Agrarian Distress in India \& CA Approach}

Agriculture, the most significant livelihood support system for the rural population and plays an important role in the Indian economy, presently the sector is under stress. During the past few decades, the agriculture sector's production performances have been declined and the sector is exposed to multiple risks and uncertainty (Barah \& Sirohi 2011). The downtrend in production and uncertainty has enhanced the vulnerability of income. Gradual degradation of soil and water resource due to intensive tillage has increased the un-sustainability of farm practice. Growing frequency of farmer's suicide in Maharashtra, Karnataka, Telangana, Madhya Pradesh, Chhattisgarh, Andhra Pradesh and Tamil Nadu (Seven states account more 
than $87 \%$ of total farmer's suicide in India) have been described the worst situations of the farmers as well as agriculture sector in India. Increasing marginalization is a serious problem in India, the number of landholdings has increased but the operational area declined (Reddy \& Mishra 2010).

Labour-intensive conventional agriculture practice becomes less profitable due to slowdown in the productivity growth rate. Rise in food insecurity, hunger and deprivation are causes of the downtrend in agriculture production. Climate change, intensive tillage, increasing pressure on natural resources, groundwater depletion, gradual degradation of soil and water quality, second-hand technology, conventional monoculture, traditional practice and falling in soil fertility are major hectic factors for agriculture sustainability in India. Agrarian distress in India is increasing in recent times due to various reasons.

Figure 01: Flow Diagram Shows the Potential Benefit of CA Approaches

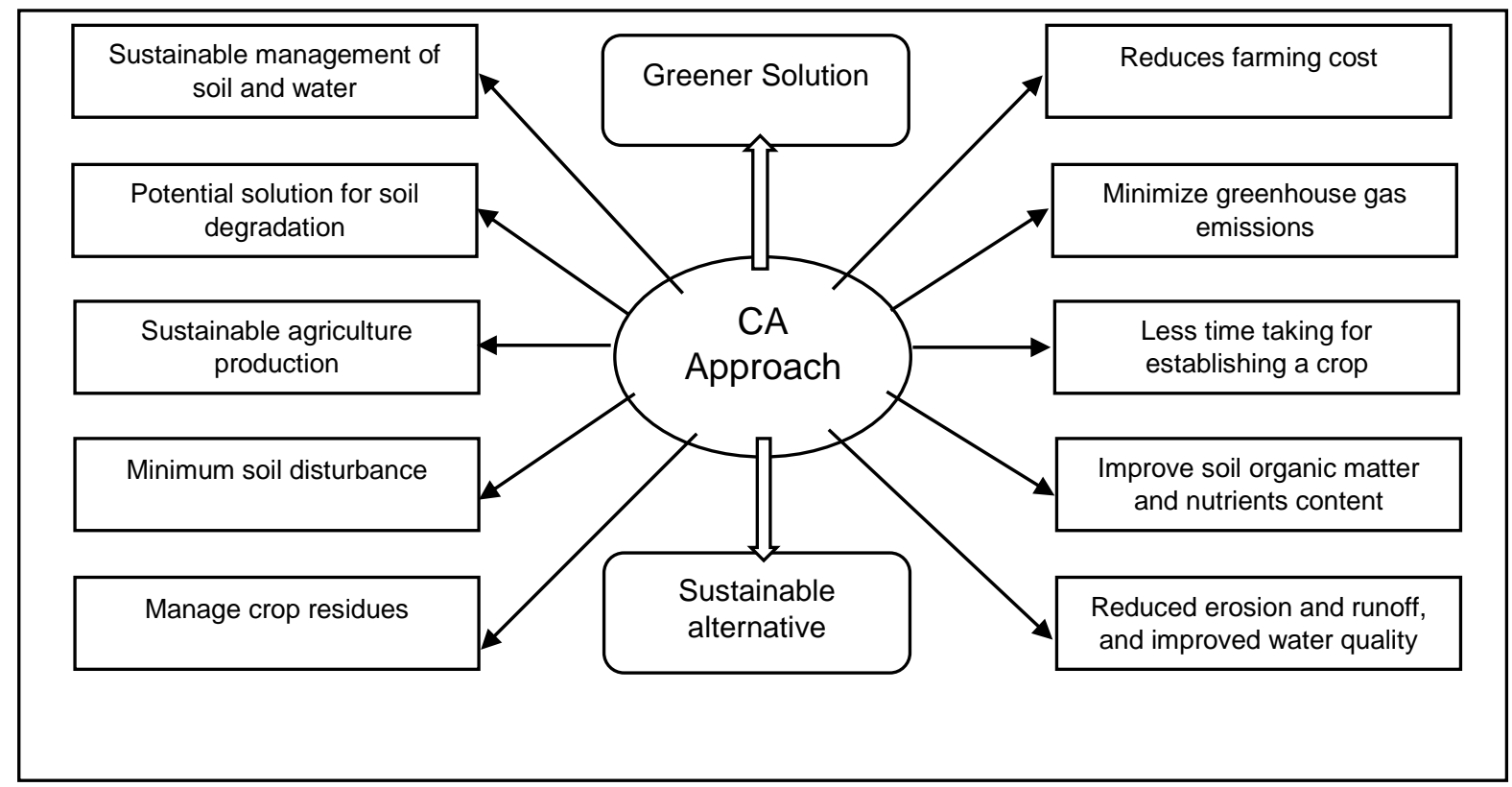

Source: Prepared by Author

\section{Land Degradation}

India accounts for 5,334 million tonnes of soil loss every year due to soil erosion. A study estimates 26 billion tons of topsoil loss per year due to human activity, which is 2.6 times the natural rates of soil degradation (Verhulst et al., 2010). Gradual land degradation creates new sets of challenges for agriculture sustainability. Modern agriculture practice also the causes of land degradation. The green revolution has introduced massive use of chemical fertilizers and pesticide which has caused a significant decline in the floral and faunal population. Industrialization, population explosion, urbanization, intensive cultivation, deforestation, shifting cultivation, mining and overgrazing are the principal causes of land degradation in India. According to an estimates 147 million hectares of land in India affected by water erosion (94 Mha), acidification (16 Mha), flooding (14 Mha), wind erosion (9 Mha), salinity (6 Mha) and combination factors ( $7 \mathrm{Mha}$ ). A satellite imagery-based estimates find out, 80 Mha cultivated area is substantially degraded. Land degradation is a serious problem in India, its high time to tackle the situation. Table-1 shows state-wise land degradation phenomena in India and, Data displays every state affected by land degradation. Table- 2 shows the process and causes of land degradation and the importance of conservation approach to check soil disturbances. 
Table0 1: State-Wise Land Degradation in India (Mha)

\begin{tabular}{|l|c|c|l|c|c|}
\hline State & $\begin{array}{c}\text { Total } \\
\text { Degraded } \\
\text { Area }\end{array}$ & $\begin{array}{c}\text { Percent of } \\
\text { Degraded Area } \\
\text { to TGA }\end{array}$ & State & $\begin{array}{c}\text { Total } \\
\text { Degraded } \\
\text { Area }\end{array}$ & $\begin{array}{c}\text { Percent of } \\
\text { Degraded } \\
\text { Area to TGA }\end{array}$ \\
\hline $\begin{array}{l}\text { Andhra } \\
\text { Pradesh \& } \\
\text { Telangana }\end{array}$ & 15.0 & 54.5 & Jammu \& Kashmir & 7.0 & 31.6 \\
\hline Goa & 0.2 & 43.9 & $\begin{array}{l}\text { Uttar Pradesh \& } \\
\text { Uttarakhand }\end{array}$ & 15.3 & 52.0 \\
\hline Karnataka & 7.6 & 39.8 & Delhi & 0.1 & 55.4 \\
\hline Kerala & 2.6 & 67.1 & Haryana & 1.5 & 33.2 \\
\hline Tamil Nadu & 5.3 & 41.0 & Punjab & 1.3 & 25.4 \\
\hline Manipur & 1.9 & 42.6 & Bihar \& Jharkhand & 6.3 & 36.1 \\
\hline Mizoram & 1.9 & 89.2 & West Bengal & 2.8 & 31.0 \\
\hline Meghalaya & 1.2 & 53.9 & Union Territories & 0.2 & 24.8 \\
\hline Assam & 2.2 & 28.2 & Gujrat & 8.1 & 41.5 \\
\hline $\begin{array}{l}\text { Arunachal } \\
\text { Pradesh }\end{array}$ & 0 & 53.8 & Rajasthan & 11.4 & 33.2 \\
\hline Nagaland & 1.0 & 60.0 & $\begin{array}{l}\text { Madhya Pradesh \& } \\
\text { Chhattisgarh }\end{array}$ & 26.2 & 59.1 \\
\hline Sikkim & 0.2 & 33.0 & Maharashtra & 13.1 & 42.4 \\
\hline Tripura & 0.6 & 59.9 & Orissa & 6.1 & 39.3 \\
\hline $\begin{array}{l}\text { Himachal } \\
\text { Pradesh }\end{array}$ & 4.2 & 75.0 & Grand Total (Mha) & 146.8 & \\
\hline
\end{tabular}

Source: Reference 6 (Bhattacharyya et al., 2015)

TGA is Total Ground Area

Table 02: Land Degradation Processes, Major Causes and CA Approach

\begin{tabular}{|c|c|c|}
\hline $\begin{array}{l}\text { Processes of land } \\
\text { degradation }\end{array}$ & Causes & CA system approach \\
\hline Soil erosion & $\begin{array}{l}\text { Water runoff } \\
\text { Deforestation } \\
\text { Land tillage } \\
\text { Over grazing } \\
\text { Quarrying and mining } \\
\text { Unsustainable agriculture practices }\end{array}$ & \multirow{5}{*}{$\begin{array}{l}\text { Conservation agriculture avoids soil } \\
\text { disturbance by direct seeding, thus will } \\
\text { be helpful to improve organic mulch } \\
\text { cover on the soil surface. } \\
\text { CA manages crop residues, that } \\
\text { techniques are highly beneficial to } \\
\text { improve soil fertility and also helpful in } \\
\text { reducing soil erosion. } \\
\text { CA system enhances rainfall infiltration } \\
\text { capacity and reduced runoff and soil } \\
\text { erosion. } \\
\text { The problem of salinization can be } \\
\text { reduced with CA. no-till and surface } \\
\text { retention of residues limits the } \\
\text { evaporation. the no-till agricultura } \\
\text { practice also improves soil structure in } \\
\text { the long-term. } \\
\text { Conservation agriculture is significant } \\
\text { to improve soil nutrient supplies and } \\
\text { cycling, that is favorable for enhancing } \\
\text { the bio-chemical decomposition of } \\
\text { organic crop residues at the soil } \\
\text { horizon. } \\
\text { CA principles protect soil from raindrop } \\
\text { impact. }\end{array}$} \\
\hline Soil contamination & $\begin{array}{l}\text { Waste disposal } \\
\text { Excessive use of pesticides and } \\
\text { herbicide } \\
\text { Intensive cultivation }\end{array}$ & \\
\hline Desertification & $\begin{array}{l}\text { Drought, } \\
\text { Reduction in vegetation cover, } \\
\text { Wrong agricultural management } \\
\text { practices, } \\
\text { Excessive grazing, } \\
\text { Cultivation on marginal land } \\
\text { Over-exploitation of the natural } \\
\text { resources and ground water. }\end{array}$ & \\
\hline Soil acidification & $\begin{array}{l}\text { The application of ammonium-based } \\
\text { nitrogen fertilizer } \\
\text { Long term use of anhydrous } \mathrm{NH} 3 \text { and } \\
\text { urea } \\
\text { Excessive leaching }\end{array}$ & \\
\hline Soil salinity & $\begin{array}{l}\text { Excessive use of water for irrigation, } \\
\text { High rate of evaporation } \\
\text { Fluctuations of water table }\end{array}$ & \\
\hline
\end{tabular}

\section{Climate Change}

Modern agricultural technology and approach is a serious factor for climate change. Modern agricultural sector is responsible for about 30 per cent of the total greenhouse gas (CO2, N2O, $\mathrm{CH} 4$ ) emissions (Kassam et al., 2009). Extremely growing climatic events are the 
consequences of climate change, which affects more and more in the agriculture sector. Wheat performance of India and wheat yields decreased due to global warming and temperature increased enhance vulnerability in soybean crops in central India. Agriculture and cereal production are significantly affected by climate change. Table and diagram showing various distress in the agriculture sector in India

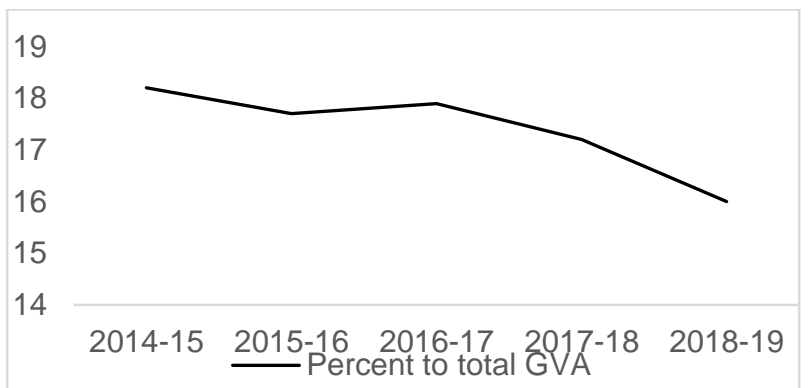

Figure 2: Continuous decline in the share of agriculture sector in the GVA. Source: Central Statistics Office, MOSPI,

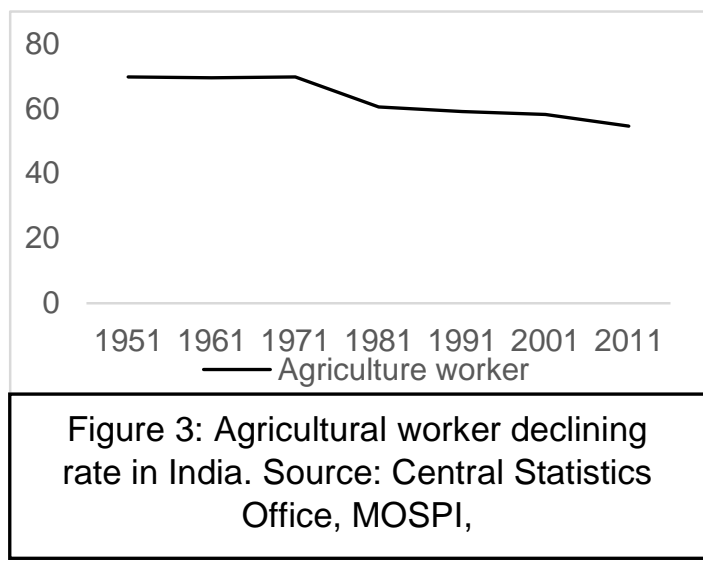

Table 03: Estimated Data of Monthly Income \& Indebted Agricultural Households

\begin{tabular}{|l|c|c|c|}
\hline State & $\begin{array}{l}\text { Average monthly income per } \\
\text { agriculture household (Rs.) }\end{array}$ & State & $\begin{array}{c}\text { Indebted Agricultural } \\
\text { household (\%) }\end{array}$ \\
\hline Bihar & 3558 & Andhra Pradesh & 92.9 \\
\hline Jharkhand & 4721 & Telangana & 89.1 \\
\hline Odisha & 4976 & Tamil Nadu & 82.5 \\
\hline Uttar Pradesh & 4701 & Kerala & 77.7 \\
\hline Uttaranchal & 4923 & Karnataka & 77.3 \\
\hline West Bengal & 3980 & Rajasthan & 61.8 \\
\hline All India & 6426 & All India & 51.9
\end{tabular}

Source: situation assessment survey of agriculture household (Jan-Dec 2013), NSSO

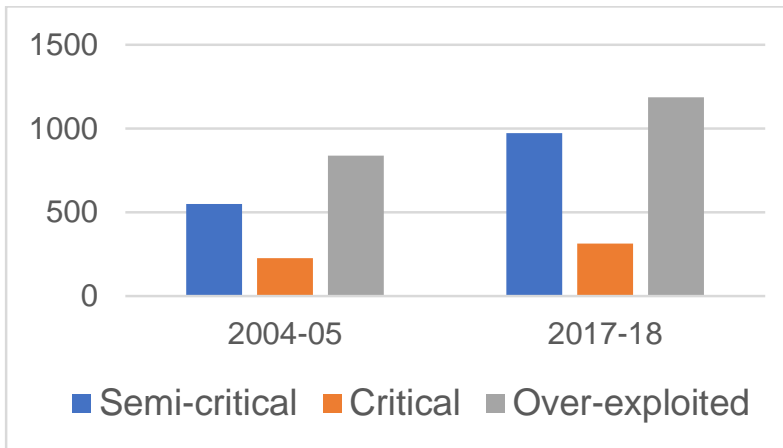

Figure 4: Categorization of Blocks/ Mandals/ Talukas in India, based on groundwater. Source: Central Ground Water Board

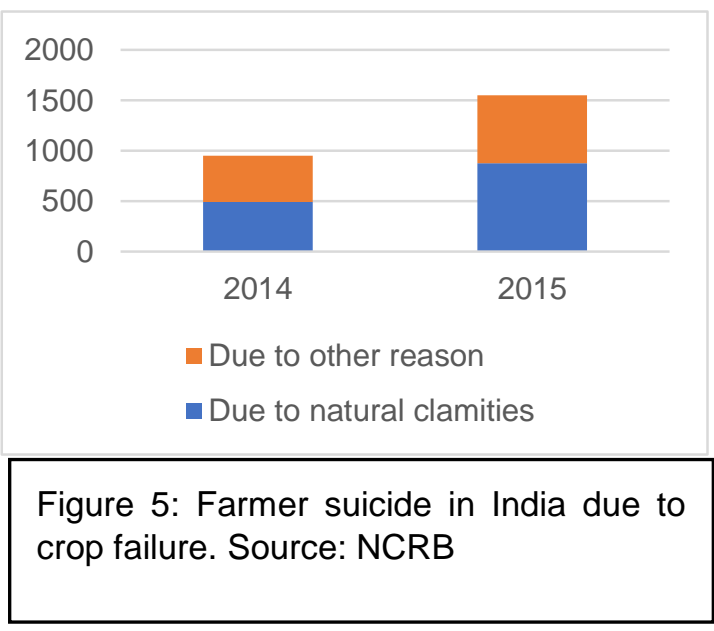

Figure-2,3,4 and 5 displays the pathetic situation of the agricultural sector in India. Percentage of total agriculture workers and the share of agriculture sector in the GVA are continuously declining and, farmers suicide is a terrific puzzle in India. More than 50 per cent of farmer suicide occurred in India due to natural calamities, which is a big reason for crop failure. Table-3 shows six states average monthly income per agriculture household. Bihar accounts minimum household income and Andhra Pradesh account a maximum percentage of indebted agriculture household in India. 


\section{Potentials of Conservation Agriculture}

- Conservation agriculture is an alternative paradigm to reduce greenhouse gas emissions and it's an effective no-till system for enhancing biological activity in soils.

- Sustainable management of agro-ecosystems is a major concern of the CA approach, thus promote the goal of production sustainability, increased profits, and farm income by preserving the environment and natural resource base.

- Conservation agriculture practices are interlinked with climate-smart agriculture that seeks to increase yields in an environmentally and socially sustainable way.

- CA system raise farm output, production efficiency and maintain the flow of ecosystem services including soil and water conservation.

- CA involves crop rotations to help reduce possible weed, disease and pest problems and beneficial to minimize crop failure risk. Crop rotation can promote more stable aggregation in soil.

- Soil mesofauna, macro fauna and earthworm may be lost by abrasion during tillage operation. CA implies zero tillage without disturbance of the soil.

- No-tillage and crop residue retention increased microbial diversity, that species play a significant role to maintain soil health.

\section{Conclusion}

Conservation agriculture practice offers a green paradigm for agricultural development, which is more sustainable and resources conserving technique in comparison to the conventional and traditional system. Land degradation, potential threats of climate change, crop failure and production uncertainty have increased the demand for new and more suitable cropping techniques that enhance production with conserving natural resource base. Conservation agriculture technology is an opportunity for India to reduce production cost, enhance crop diversification, save water and natural nutrients and reduce greenhouse gas emissions from agriculture. We have to take more research initiative on how to promote CA approach in India in the context of small landholding and heavy population pressure on land.

\section{References}

1. Abrol, I.P. and Sangar, S., 2006. Sustaining Indian agriculture-conservation agriculture the way forward. Current Science, pp.1020-1025.

2. Almaraz, J.J., Zhou, X., Mabood, F., Madramootoo, C., Rochette, P., Ma, B.L. and Smith, D.L., 2009. Greenhouse gas fluxes associated with soybean production under two tillage systems in south-western Quebec. Soil and Tillage Research, 104(1), pp.134-139.

3. Arya, A.S., Dhinwa, P.S., Pathan, S.K. and Raj, K.G., 2009. Desertification/land degradation status mapping of India. Current Science, pp.1478-1483.

4. Barah, B.C. and Sirohi, S. eds., 2011. Agrarian Distress in India: Problems and Remedies. Concept Publishing Company.

5. Bhan, S. and Behera, U.K., 2014. Conservation agriculture in India-Problems, prospects and policy issues. International Soil and Water Conservation Research, 2(4), pp.1-12.

6. Bhattacharyya, R., Ghosh, B.N., Mishra, P.K., Mandal, B., Rao, C.S., Sarkar, D., Das, K., Anil, K.S., Lalitha, M., Hati, K.M. and Franzluebbers, A.J., 2015. Soil degradation in India: Challenges and potential solutions. Sustainability, 7(4), pp.3528-3570.

7. Chauhan, B.S., Mahajan, G., Sardana, V., Timsina, J. and Jat, M.L., 2012. Productivity and sustainability of the rice-wheat cropping system in the Indo-Gangetic Plains of the Indian subcontinent: problems, opportunities, and strategies. In Advances in Agronomy (Vol. 117, pp. 315-369). Academic Press.

8. Dendooven, L., Gutiérrez-Oliva, V.F., Patiño-Zúñiga, L., Ramírez-Villanueva, D.A., Verhulst, N., Luna-Guido, M., Marsch, R., Montes-Molina, J., Gutiérrez-Miceli, F.A., Vásquez-Murrieta, S. and Govaerts, B., 2012. Greenhouse gas emissions under conservation agriculture compared to traditional cultivation of maize in the central highlands of Mexico. Science of the Total Environment, 431, pp.237-244.

9. Dwivedy, N., 2011. Challenges faced by the Agriculture Sector in Developing Countries with special reference to India. International journal of rural studies, 18(2).

10. Giller, K.E., Witter, E., Corbeels, M. and Tittonell, P., 2009. Conservation agriculture and smallholder farming in Africa: the heretics' view. Field crops research, 114(1), pp.23-34. 
11. Ghosh, P.K., Das, A., Saha, R., Kharkrang, E., Tripathi, A.K., Munda, G.C. and Ngachan, S.V., 2010. Conservation agriculture towards achieving food security in North East India. Current Science, pp.915-921.

12. Govaerts, B., Fuentes, M., Mezzalama, M., Nicol, J.M., Deckers, J., Etchevers, J.D., FigueroaSandoval, B. and Sayre, K.D., 2007. Infiltration, soil moisture, root rot and nematode populations after 12 years of different tillage, residue and crop rotation managements. Soil and Tillage Research, 94(1), pp.209-219.

13. Gulati, A., Kumar, A.G., Shreedhar, G. and Nandakumar, T., 2012. Agriculture and malnutrition in India. Food and nutrition bulletin, 33(1), pp.74-86.

14. Hobbs, P.R., Sayre, K. and Gupta, R., 2008. The role of conservation agriculture in sustainable agriculture. Philosophical Transactions of the Royal Society B: Biological Sciences, 363(1491), pp.543-555.

15. Heidhues, F.R.A.N.Z. and Brüntrup, M., 2003. Subsistence agriculture in development: Its role in processes of structural change. Subsistence agriculture in Central and Eastern Europe: How to break the vicious circle, 1 .

16. Kassam, A., Friedrich, T., Shaxson, F. and Pretty, J., 2009. The spread of conservation agriculture: justification, sustainability and uptake. International journal of agricultural sustainability, 7(4), pp.292-320.

17. Neate, P.J., 2013. Climate-smart agriculture: success stories from farming communities around the world.

18. Palm, C., Blanco-Canqui, H., DeClerck, F., Gatere, L. and Grace, P., 2014. Conservation agriculture and ecosystem services: An overview. Agriculture, Ecosystems \& Environment, 187, pp.87-105.

19. Reddy, D.N. and Mishra, S. eds., 2010. Agrarian crisis in India. Oxford University Press.

20. Sanderson, M.A., Archer, D., Hendrickson, J., Kronberg, S., Liebig, M., Nichols, K., Schmer, M., Tanaka, D. and Aguilar, J., 2013. Diversification and ecosystem services for conservation agriculture: Outcomes from pastures and integrated crop-livestock systems. Renewable agriculture and food systems, 28(2), pp.129-144.

21. Sharma, K.D. and Soni, B. eds., 2006. Land use diversification for sustainable rainfed agriculture. Atlantic Publishers \& Dist.

22. Swaminathan, M.S. ed., 2007. Agriculture cannot wait: new horizons in Indian agriculture. Academic Foundation.

23. Thierfelder, C., Cheesman, S. and Rusinamhodzi, L., 2012. A comparative analysis of conservation agriculture systems: Benefits and challenges of rotations and intercropping in Zimbabwe. Field crops research, 137, pp.237-250.

24. Verhulst, N., Govaerts, B., Verachtert, E., Castellanos-Navarrete, A., Mezzalama, M., Wall, P., Deckers, J. and Sayre, K.D., 2010. Conservation agriculture, improving soil quality for sustainable production systems. Advances in soil science: food security and soil quality, 1799267585, pp.137-208. 